\title{
Extrinsic Factors Influence Phenology of the Epiphytic Hand Fern (Cheiroglossa palmata)
}

\begin{tabular}{|r|l|}
\hline Journal: & Botany \\
\hline Manuscript ID & cjb-2017-0071.R1 \\
\hline Manuscript Type: & Article \\
\hline Date Submitted by the Author: & 23-Jun-2017 \\
\hline Complete List of Authors: & $\begin{array}{l}\text { Noland, Katrina; Bok Tower Gardens } \\
\text { Norman, Eliane; Stetson University } \\
\text { Peterson, Cheryl; Bok Tower Gardens } \\
\text { Richardson, Matthew; University of the District of Columbia, CAUSES }\end{array}$ \\
\hline $\begin{array}{r}\text { Is the invited manuscript for } \\
\text { consideration in a Special } \\
\text { Issue? : }\end{array}$ & N/A \\
\hline Keyword: & $\begin{array}{l}\text { Ophioglossaceae, Ophioglossum palmatum, precipitation, temperature, } \\
\text { sporangial dehiscence }\end{array}$ \\
\hline & \multicolumn{2}{|c}{} \\
\hline
\end{tabular}

\section{SCHOLARONE}

Manuscripts 
Botany

Matthew L. Richardson

University of the District of Columbia

CAUSES

4200 Connecticut Avenue, NW

Washington, DC 20008

Phone: 202-274-5947

E-mail: matthew.richardson@udc.edu

Extrinsic Factors Influence Phenology of the Epiphytic Hand Fern (Cheiroglossa palmata)

\author{
Katrina Noland, Eliane Norman, Cheryl L. Peterson, and Matthew L. Richardson
}

K. Noland and C.L. Peterson. Bok Tower Gardens, 1151 Tower Blvd, Lake Wales, FL 33853, USA

E. Norman. Department of Biology, Stetson University, 421 N Woodland Blvd, Deland, FL 32723, USA

M.L. Richardson. College of Agriculture, Urban Sustainability and Environmental Sciences, University of the District of Columbia, 4200 Connecticut Avenue, NW, Washington, DC 20008, USA

Corresponding author: Katrina Noland (e-mail: knoland@boktower.org) 


\begin{abstract}
We sought to answer the following questions about the epiphytic hand fern, Cheiroglossa palmata (L.) C. Presl: 1) are longevity and morphology of leaves influenced by field site and host tree; and 2) are leaf mortality, emergence, growth, and sporangial dehiscence influenced by weather? We monitored survival, morphology, emergence, growth, and dehiscence for 27 months at wet and dry field sites. We tested for correlations between phenology and weather from 0-3, 4-6, and 7-9 months before a field survey. More morphological traits were influenced by the tree in which a fern grew than field site. However, leaves at the wet site had longer blades, sporangial clusters, and sporophore stalks and lived longer. More leaves emerged when precipitation and temperatures were higher within the prior 3 months. Leaves grew longer when precipitation was higher within 0-6 months and minimum temperature was higher within 4-6 months. Dehiscence was positively correlated with the number of days of precipitation within 3 months. Emergence, growth, and dehiscence were negatively correlated with some measures of temperature and precipitation, especially higher precipitation within 7-9 months. Our results indicate an important, but complicated, impact of seasonal variation in temperatures and precipitation on the phenology of hand fern.
\end{abstract}

Key words: growth, Ophioglossaceae, Ophioglossum palmatum, precipitation, sporangial dehiscence, temperature 


\section{Introduction}

Phenology is the study of cyclical and seasonal changes in biological processes, such as plant growth and reproduction, and their relationship with abiotic and biotic factors (Lieth 1974). Phenology of plants is often driven by weather and photoperiod, and changes in phenology due to climate change have received a great deal of attention (e.g., Iler and Inouye 2013; Iler et al. 2013). Most phenological studies, however, have focused on flowering plants, whereas ferns have received much less attention. Understanding fern phenology, and how the environment influences phenology, is important to understand the biology and ecology of a species, and develop robust programs to maintain and restore populations of species of conservation concern.

The growth and fertility of ferns may respond primarily to seasonal changes in temperature and precipitation because they do not need animals for reproduction or dispersal (Barrington 1993; Mehltreter 2006). Several studies have shown that leaf emergence and mortality, leaf growth, and fertility of ferns occur seasonally and are often influenced by temperature and/or precipitation in temperate regions with distinct seasons or in tropical regions with distinct wet and dry seasons (Farrar 1976; Odland 1995; Sharpe 1997; Arens 2001; Mehltreter and Palacios-Rios 2003; Lee et al. 2016). For example, emergence, growth, and mortality of leaves of the climbing fern Lygodium venustum Sw. all increased during the rainy season in Mexico (Mehltreter 2006). The leaves of the tree fern Alsophila firma (Baker) D. S. Conant were shed during the rainy season in Mexico and most plants stayed leafless for at least a month before producing a synchronized flush of new leaves (Mehltreter and García-Franco 2008). Little work on fern phenology has occurred in the subtropics, but 16 species in Taiwan showed varying phenological responses that were due primarily to precipitation (e.g., emergence of fertile leaves) or temperature (e.g., leaf emergence, expansion and mortality, and spore 
maturation and release; Lee et al. 2009). Also, leaf emergence, senescence, and fertility of the tree fern Cyathea corcovadensis (Raddi) Domin were correlated, in part, with temperature in subtropical Brazil (Neumann et al. 2014). Despite some evidence that phenology often responds to temperature and precipitation, not all phenological rhythms do (Tryon 1960; Moran 1986). For example, leaf mortality and growth of the herbaceous tropical fern Didymochlaena truncatula (Sw.) J. Sm were correlated with precipitation, but fertility and leaf production were not (Farias et al. 2015).

The hand fern, Cheiroglossa palmata (L.) C. Presl (=Ophioglossum palmatum L.) (Ophioglossaceae), is an evergreen perennial found primarily in the New World Tropics, but also in parts of Africa and Asia (Mesler 1974). Despite its wide range, it is rare where it is found (Dittrich et al. 2005; Norman, unpubl. data) and is state-listed as endangered in Florida. Conservation efforts of this rare fern are impeded because little is known about its biology and ecology. There are more than 80 species in the family Ophioglossaceae, but hand fern is unusual because it is epiphytic and palmately lobed (Mesler 1974). It grows in wet regions and microsites where desiccation is less of a risk (Mesler 1974). In Florida, it grows in humid areas adjacent to Cypress ponds or streams and grows almost exclusively in the moist humus that collects in the leaf bases of cabbage palms, Sabal palmetto (Walt.) Lodd.

Given the published correlations between environmental conditions and fern phenology broadly and observations that wet, humid sites support more hand ferns specifically, we decided to test for correlations between environmental conditions and the phenology of hand ferns. We selected a wet site and dry site within Tosohatchee Wildlife Management Area (Christmas, FL) and observed and measured hand fern phenology for over two years to determine 1) whether longevity and morphology of leaves were influenced by the palm tree in which it was growing 
and field site, and 2) whether leaf mortality, leaf emergence, growth, and timing of spore release (hereafter "dehiscence") were influenced by precipitation and temperature. Epiphytic ferns may be particularly sensitive to changes in habitat because they are reliant on conditions of the tree in which they grow (Sinclair 1999). Therefore, we predicted that the longevity and morphology of leaves would differ between trees and sites due to differences in micro and macrohabitat. We also predicted that phenology would be influenced strongly by precipitation and temperature because central Florida experiences marked seasonality in these two climate factors.

\section{Materials and Methods}

Hand fern leaves are lobed and can bear as many as 15 sporophores, which are fertile spikes that consist of a stalk and a sporangial cluster that bears two rows of sporangia (Fig. 1; Mesler 1974). Some leaves lack sporophores. Leaves usually grow in clusters, which may be individual plants and we will refer to them as such in this paper. However, we cannot be certain whether plants are connected by roots under the palm boots. We surveyed hand fern within two sites at the Tosohatchee Wildlife Management Area: one site was found on the edge of an old road bed and was relatively dry, whereas the second site was in a small seasonal cypress pond and was therefore a wet site. Specific geographical locations of the study sites are not given to protect remaining populations of this endangered species.

In 2003 we randomly chose 4 trees at the dry site and 12 trees at the wet site to monitor hand fern. The position of each tree was recorded and assigned a unique label in a handheld GPS unit. We labeled each hand fern plant by writing a number on the base of the cabbage palm leaf in which the fern plant grew. Each hand fern leaf that we could reach from ground level was labeled with a piece of uniquely colored wire. We visited one site each month, alternating the site 
we visited so that each site was visited once every two months from May 2003 through May 2006. Because we needed to know when each leaf emerged, we present results starting with March 2004, at which point we had seen enough new leaves start growing to get an adequate sample size. During each site visit we noted whether new leaves had appeared since our prior visit, if leaves were alive or dead, if at least one sporophore was present, and if sporangias dehisced. Dehiscence was indicated by sporangial clusters changing from green to yellow, which seemed to occur simultaneously for all sporophores on a single leaf at the time intervals we used for sampling. We also measured the length of leaf petioles, the length and width of leaf blades, counted the number of lobes and sporophores, and calculated the mean length of sporophore stalks and sporangial clusters that grew from each leaf. We present measurements of sporophore stalks and sporangial clusters only when the latter dehisced.

\section{Data analysis}

Longevity of leaves (longevity $=$ month of death - month of emergence) was compared between the wet and dry sites using a generalized linear model (PROC GLM; SAS Institute 2008). Trees were nested within site in the statistical model and longevity of leaves from a single plant was averaged before analysis. We only included a fern plant in the statistical model if it had a minimum of three leaves, and a tree if it had a minimum of three hand fern plants, so 286 leaves from 32 plants and three trees were included from the dry site and 140 leaves from 31 plants and four trees were included from the wet site.

Differences in leaf morphology due to tree in which it grew and site were also analyzed using generalized linear models (PROC GLM; SAS Institute 2008). Trees were nested within site in all statistical models. Only the maximum measurement for each morphological trait was used 
from each leaf, and the measurements from all leaves from a single plant were averaged for each morphological trait. As previously described, we only included a fern plant in the statistical models if it had a minimum of three leaves, and a tree if it had a minimum of three hand fern plants. So, 215 leaves from 29 plants and three trees were included from the dry site and 111 leaves from 24 plants and four trees were included from the wet site. The number of leaves and ferns used for this analysis is lower than the number used to calculate longevity because of missing morphological data. The length of leaf petioles was log10 transformed and the number of sporophores was square-root transformed to meet assumptions of normality. We present the mean and standard error of the mean (SEM) of non-transformed data in the Results. Many leaves did not develop sporophores, and fern species often produce sterile leaves, but these zeroes were included in the analysis because of the possibility that this lack of fertility was influenced by extrinsic factors.

Daily minimum and maximum temperatures and precipitation from June 2003 through May 2006 were obtained from the closest weather station in Titusville, FL, which is approximately $22 \mathrm{~km}$ from our field site (Fig. 2). We used multiple regression (PROC REG; SAS Institute 2008) to look for correlations between weather and leaf emergence, growth, dehiscence, and mortality (after Iller and Inouye 2013). We used the number of days with precipitation, mean total precipitation, mean minimum temperature, and mean maximum temperature as independent variables. We further divided the weather data into three time periods to look for correlations with hand fern phenology: 0-3, 4-6, and 7-9 months prior to each survey date. This method of dividing weather into time periods allows us to evaluate immediate and delayed phenological responses to a given environmental stimulus as well as take Florida's 
seasonality into account. The final models were selected using Akaike information criterion (AIC) values, wherein the lowest AIC value indicates the model that best fits the data.

Only a single value for leaf emergence, growth, dehiscence, and mortality from each survey date was used in the linear regressions. To derive a single value for leaf emergence, we first noted the number of leaves that had newly emerged since the prior survey period. For each plant that had a minimum of three leaves within a survey date, we calculated the percentage of new leaves. We then calculated the percentage of new leaves across all trees that had a minimum of three plants across all dates of the study. Leaf growth was calculated by the percent change in centimeters in blade length between survey periods, dehiscence was calculated as the percent of all leaves that had sporophores that clearly released spores since the prior survey, and mortality was calculated as the percentage of leaves that died since the prior survey. To derive a single mean per survey date for growth, dehiscence, and mortality, we used the same methods as described for leaf emergence: each plant had to have a minimum of three leaves and each tree had to have a minimum of three plants to be included in the analysis. Ensuring that we had this replication reduced the overall number of leaves included in the analysis as well as the number of trees. The number of trees included in these analyses was a minimum of three at the dry site and six at the wet site.

\section{Results}

Longevity of leaves was $11.9 \pm 0.86$ months in the wet site and $7.3 \pm 0.59$ months in the dry site $(F=26.4, \mathrm{df}=1, P<0.001)$, and longevity was also influenced by the host tree $(F=$ $4.25, \mathrm{df}=5, P=0.002$ ). Four of the seven morphological characteristics differed among trees 
and three varied between the two sites (Table 1). Leaves, on average, were longer and produced longer sporangial clusters and sporophore stalks in the wet site (Table 1).

Weather was correlated with leaf emergence, growth, and dehiscence, but was not correlated with mortality (Table 2). New leaves emerged when mean precipitation, maximum temperature, and minimum temperature were higher in the prior 0-3 months, when the minimum temperature was lower in the prior 4-6 months, and when the number of days with precipitation and the mean precipitation were lower in the prior 7-9 months (Table 2). New leaves emerged most often in the months of August through October (Fig. 3A). The prior 0-3 months would be approximately from May (3 months prior to August leaf emergence) through October (0 months prior to October leaf emergence), the prior 4-6 months would be February (6 months prior to August leaf emergence) through July (4 months prior to October leaf emergence), and the prior 7-9 months would be November of the prior year ( 9 months prior to August leaf emergence) through April of the current year ( 7 months prior to October leaf emergence). Therefore, wetter hotter periods from late spring through early autumn, cooler periods from winter through midsummer, and drier periods from winter through early spring were most favorable for leaf emergence.

The growth rate of leaves was the highest when the mean precipitation was higher in the prior 0-3 and 4-6 months, minimum temperature was higher in the prior 4-6 month, and mean precipitation, maximum temperature, and minimum temperature were lower in the prior 7-9 months (Table 2). Growth rate was highest in July, September, and October in 2004 and September through November in 2005 (Fig. 3B). Using September and October as a reference, the prior 0-3 months would be approximately from June through October, the prior 4-6 months would be March through July, and the prior 7-9 months would be December (of the prior year) 
through March. Therefore, wetter periods in summer through early autumn, wetter periods with warmer minimum temperatures in spring, and cooler drier winters were most favorable for growth of leaves.

Dehiscence was highest when the number of days with precipitation and the minimum temperature were higher in the prior 0-3 months, when the mean precipitation and maximum temperature were lower in the prior 4-6 months, and when the mean precipitation, number of days with precipitation, maximum temperature, and minimum temperature were all lower in the prior 7-9 months (Table 2). Dehiscence was more variable than leaf production and growth: there are peaks of dehiscence in April and June through August in 2004, but June and August only in 2005 (Fig. 3C). Using June through August as a reference, the prior 0-3 months would be approximately from March through August, the prior 4-6 months would be December (of the prior year) through May, and the prior 7-9 months would be September (of the prior year) through February. Therefore, more days of rain and higher minimum temperature in spring through late summer and cooler drier autumns, winters, and springs were most favorable for dehiscence.

\section{Discussion}

As we predicted, longevity of leaves differed between the two sites and leaves lived over four months longer in the wet site. As we also predicted, the morphology of hand fern leaves differed among trees and sites. The morphological differentiation of ferns among trees may indicate that microhabitat had an influence, that genetic relatedness of hand ferns within trees was closer than between trees, or that a microhabitat $\mathrm{x}$ genetic interaction influenced fern morphology. Leaves were generally 1.4 times longer at the wet site and had longer sporangial clusters and sporophore 
stalks. Our results may provide indirect evidence that differences in water availability within a site have consequences for hand fern, but differences in nutrient availability, light, and other abiotic conditions cannot be ruled out. Collectors and human development that altered hydrology decimated this once relatively abundant species in southern Florida (Mesler 1974). These same pressures apply in central Florida, too.

Three of the four phenological events we studied, leaf emergence, growth, and dehiscence, were correlated with temperature and precipitation, whereas leaf mortality was not. It is not unusual for some phenological events to be correlated with weather and not others because other extrinsic and intrinsic factors, such as soil temperature, photoperiod, and stored nutrients, may influence fern phenology (Odland 1995; Landi et al. 2014; Neumann et al. 2014). Prior studies on ferns usually looked for correlations between fern phenology and only the prior 0-2 months of weather, perhaps because most of those studies focused on tropical species that experienced little seasonality (Mehltreter 2006; Mehltreter and García-Franco 2008; Landi et al. 2014; Farias et al. 2015). To our knowledge, our study is the first on a fern species to include nearly three-quarters of the prior year. We found that temperature and precipitation immediately before and up to 9 months prior influence phenology. A lengthy time lag between weather and a phenological event is more commonly reported for flowering plants (e.g., Iler and Inouye 2013). Our results indicate that the impact seasonal variation in temperatures and precipitation has on hand fern phenology is important, but not straightforward. New leaves emerged most often in August through October and leaf growth is highest in approximately September through October, which is in the latter part of the rainy season in Florida. Hot and wet weather immediately preceded the production of new leaves, but cooler, drier weather preceding the hot, rainy season was also correlated with leaf production. Recent precipitation is more highly 
correlated with growth than temperature, but, similarly to leaf emergence, a cooler, drier season needs to precede the rainy season to achieve maximum growth, which is the normal weather pattern in Florida. The peaks in growth rate also coincide with the appearance of new leaves. Fern leaves commonly grow at their fastest rate within the first month after emerging (Schmitt and Windisch 2012; Farias et al. 2015). Prior observational work found that sporophores matured between December and May (Mesler 1974), but peaks of dehiscence at our study sites were during April and June through August. Perhaps the differences in timing of dehiscence between our study and the one in 1974 are due to differences in field methods, field sites, or a shift in climate. Dehiscence was much more variable across months than leaf emergence and growth, but followed the same relative cues as leaf emergence and growth: a warmer and wetter season preceded by a cooler, drier season.

We would have to extend our work for more years to accurately show how climate change influences longevity, morphology, and phenology of hand fern. However, climate change is expected to not only increase temperature, but also decrease precipitation during the months of March through August and possibly increase precipitation slightly in September through November (Misra et al. 2011). A decrease in precipitation during the traditional rainy season could alter hand fern's phenology or might cause local extinction since this plant is traditionally found in moist, tropical areas. Experimentally manipulating the amount of water ferns receive could test the impact of decreased precipitation, but may not be feasible since this is a rare plant.

\section{Acknowledgments}

We thank the Tosohatchee Wildlife Management Area for access to field sites, and Tom O'Neil, Pedro Quintano-Ascencio, Richard Wunderlin, Bruce Hansen, Richard Moyroud, Richard 
Jackson, Keith Fisher, and J.L. Hollowell for help with various aspects of this project. We thank Alan Cressler (USGS) for providing the photograph used in Figure 1, Ashley Myers for help with formatting the manuscript, and two anonymous reviewers for constructive feedback. We also thank our funding sources: the University of Central Florida Research and Mentoring Program, University of Central Florida Women's Club, Florida Park Service - Americorps, Florida Native Plant Society, and the State of Florida, Department of Agriculture and Consumer Services (grant agreement \#022645).

\section{References}

Arens, N.C. 2001. Variation in performance of the tree fern Cyathea cracasana (Cyatheaceae) across a successional mosaic in Andean cloud forest. Am. J. Bot. 88: 545-551.

Barrington, D.S. 1993. Ecological and historical factors in fern biogeography. J. Biogeogr. 20: $275-280$.

Dittrich, V.A.O., Waechter, J.L., and Salino, A. 2005. Species richness of pteridophytes in a montane Atlantic rain forest plot of Southern Brazil. Acta. Bot. Bras. 19: 519-525.

Farias, R.P., Costa, L.E.N., Silva, I.A.A., and Barros, I.C.L. 2015. Phenological studies of selected leaf and plant traits of Didymochlaena truncatula (Dryopteridaceae) in a Brazilian submontane tropical rainforest. Nord. J. Bot. 33: 249-255.

Farrar, D.R. 1976. Spore retention and release from overwintering fern fronds. Am. Fern. J. 66: 49-52.

Iler, A.M., and Inouye, D.W. 2013. Effects of climate change on mast- flowering cues in a clonal montane herb, Veratrum tenuipetalum (Melanthiaceae). Am. J. Bot. 100: 519-525. 
Iler, A.M., Høye, T.T., Inouye, D.W., and Schmidt, N.M. 2013. Nonlinear flowering responses to climate: are species approaching their limits of phenological change? Philos. T. R. Soc. B. 368: 20120489 .

Landi, M., Zoccola, A., Bacaro, G., and Angiolini, C. 2014. Phenology of Dryopteris affinis ssp. affinis and Polystichum aculeatum: modeling relationships to the climatic variables in a Mediterranean area. Plant Spec. Biol. 29: 129-137.

Lee, P.H., Lin, T.T., and Chiou, W.L. 2009. Phenology of 16 species of ferns in a subtropical forest of northeastern Taiwan. J. Plant Res. 122: 61-67.

Lee, P.H., Chen, S.W., Chiou, W.L., Huang, Y.M., and Liu, H.Y. 2016. Phenology of 13 fern species in a tropical monsoon forest of southern Taiwan. Int. J. Plant Reprod. Biol. 8: 87-97.

Lieth, H. 1974. Introduction to phenology and modelling of seasonality. In: Lieth H (ed), Phenology and seasonality modelling. Springer, New York, pp. 3-19.

Mehltreter, K. 2006. Leaf phenology of the climbing fern Lygodium venustum in a semideciduous lowland forest on the Gulf of Mexico. Am. Fern. J. 96: 21-30.

Mehltreter, K., and García-Franco, J.G. 2008. Leaf phenology and trunk growth of the deciduous tree fern Alsophila firma (Baker) DS Conant in a lower montane Mexican forest. Am. Fern. J. 98: 1-13.

Mehltreter, K., and Palacios-Rios, M. 2003. Phenological studies of Acrostichum danaefolium (Pteridaceae, Pteridophyta) at a mangrove site on the Gulf of Mexico. J. Trop. Ecol. 19: $155-162$.

Mesler, M.R. 1974. The natural history of Ophioglossum palmatum in South Florida. Am. Fern. J. 64: 33-39. 
Misra, V., Carlson, E., Craig, R.K., Enfield, D., Kirtman, B., Landing, W., Lee, S.K., Letson, D., Marks, F., Obeysekera, J., Powell, M., and Shin, S.1. 2011. Climate scenarios: A Floridacentric view [online]. Florida Climate Change Task Force. Available from http://floridaclimate.org/whitepapers/.

Moran, R.C. 1986. The neotropical fern genus Olfersia. Am. Fern. J. 76: 161-178.

Neumann, M.K., Schneider, P.H., and Schmitt, J.L. 2014. Phenology, caudex growth and age estimation of Cyathea corcovadensis (Raddi) Domin (Cyatheaceae) in a subtropical forest in southern Brazil. Acta. Bot. Bras. 28: 274-280.

Odland, A. 1995. Frond development and phenology of Thelypteris limbosperma, Athyrium istentifolium and Matteuccia struthiopteris in western Norway. Nord. J. Bot. 15: 225236.

SAS Institute. 2008. SAS/STAT user's guide for personal computers. release 9.3. SAS Institute Schmitt, J.L., and Windisch, P.G. 2012. Caudex growth and phenology of Cyathea atrovirens (Langsd. and Fisch.) Domin (Cyatheaceae) in secondary forest, southern Brazil. Braz. J. Biol. 72: 397-405.

Sharpe, J.M. 1997. Leaf growth and demograghy of the rheophytic fern Thelyperis angustifolia Willdenow) Proctor in a Puerto Rican rainforest. Plant Ecol. 130: 203-212.

Sinclair, R. 1999. Epiphytes. In: Atwell BJ, Kriedemann PE, Turnbull CGN (Eds), Plants in action: adaptation in nature, performance in cultivation. Macmillan Education Australia Pty Ltd, Melbourne, Australia. Available from http://plantsinaction.science.uq.edu.au/edition1/?q=content/15-4-3-epiphytes.

Tryon, R. 1960. The ecology of Peruvian ferns. Am. Fern. J. 50: 46-55. 
Table 1. Results of generalized linear models that tested differences in morphological traits of hand fern due to tree in which the fern was located (nested within site) and site (dry versus wet site). Significant results are in bold. Means \pm SEM are given for each morphological trait at the two sites in Central Florida, USA.

\begin{tabular}{|c|c|c|c|c|}
\hline \multirow{2}{*}{$\begin{array}{l}\text { Dependent variable } \\
\text { Morphological trait }\end{array}$} & \multicolumn{2}{|c|}{ Independent variables } & \multicolumn{2}{|c|}{ Site means \pm SEM } \\
\hline & tree(site) & site & dry & wet \\
\hline Petiole length (cm) & $\mathrm{F}=5.3, \mathrm{df}=5, P<0.01$ & $\mathrm{~F}=1.5, \mathrm{df}=1, P=0.23$ & $8.1 \pm 0.76$ & $9.8 \pm 0.82$ \\
\hline Blade length (cm) & $\mathrm{F}=2.7, \mathrm{df}=5, P=0.03$ & $\mathrm{~F}=11.9, \mathrm{df}=1, P<0.01$ & $7.1 \pm 0.60$ & $10.1 \pm 0.65$ \\
\hline Blade width (cm) & $\mathrm{F}=10.6, \mathrm{df}=5, P=0.02$ & $\mathrm{~F}=0.96, \mathrm{df}=1, P=0.33$ & $4.0 \pm 0.37$ & $4.5 \pm 0.41$ \\
\hline No. of lobes & $\mathrm{F}=1.9, \mathrm{df}=5, P=0.11$ & $\mathrm{~F}=0.01, \mathrm{df}=1, P=0.92$ & $3.5 \pm 0.28$ & $3.5 \pm 0.30$ \\
\hline No. of sporophores & $\mathrm{F}=\mathbf{2 . 6 4}, \mathrm{df}=5, P=0.04$ & $\mathrm{~F}=1.7, \mathrm{df}=1, P=0.20$ & $1.5 \pm 0.27$ & $1.3 \pm 0.29$ \\
\hline Sporangial cluster length $(\mathrm{cm})$ & $\mathrm{F}=1.67, \mathrm{df}=5, P=0.19$ & $\mathrm{~F}=41.7, \mathrm{df}=1, P<0.01$ & $1.3 \pm 0.08$ & $2.2 \pm 0.12$ \\
\hline Sporophore stalk length $(\mathrm{cm})$ & $\mathrm{F}=0.65, \mathrm{df}=5, P=0.67$ & $\mathrm{~F}=12.2, \mathrm{df}=1, P<0.03$ & $2.2 \pm 0.16$ & $3.2 \pm 0.24$ \\
\hline
\end{tabular}


Table 2. Positive (+) and negative (-) correlations between phenological events of hand fern and temperature (“temp") and precipitation ("precip") in Central Florida, USA. Blank spaces indicate that an independent variable was not included in the best statistical model, which was selected using Akaike information criterion values. Number of days with precipitation in the prior 46 months is not in the table because none of the best statistical models included this variable.

\begin{tabular}{|c|c|c|c|c|c|c|c|c|c|c|c|c|}
\hline $\begin{array}{l}\text { Leaf } \\
\text { phenology }\end{array}$ & $\begin{array}{c}\text { Mean } \\
\text { precip } \\
\text { prior 0- } \\
3 \text { mo. } \\
(\mathrm{mm})\end{array}$ & $\begin{array}{c}\text { No. } \\
\text { days } \\
\text { with } \\
\text { precip } \\
\text { prior 0- } \\
3 \text { mo. }\end{array}$ & $\begin{array}{c}\text { Mean } \\
\text { max } \\
\text { temp } \\
\text { prior 0- } \\
3 \text { mo. }\end{array}$ & $\begin{array}{c}\text { Mean } \\
\text { min } \\
\text { temp } \\
\text { prior 0- } \\
3 \text { mo. }\end{array}$ & $\begin{array}{c}\text { Mean } \\
\text { precip } \\
\text { prior 4- } \\
6 \mathrm{mo} . \\
(\mathrm{mm})\end{array}$ & $\begin{array}{c}\text { Mean } \\
\text { max } \\
\text { temp } \\
\text { prior 4- } \\
6 \text { mo. }\end{array}$ & $\begin{array}{c}\text { Mean } \\
\text { min } \\
\text { temp } \\
\text { prior 4- } \\
6 \text { mo. }\end{array}$ & $\begin{array}{c}\text { Mean } \\
\text { precip } \\
\text { prior 7- } \\
9 \mathrm{mo} . \\
(\mathrm{mm})\end{array}$ & $\begin{array}{c}\text { No. } \\
\text { days } \\
\text { with } \\
\text { precip } \\
\text { prior } 7- \\
9 \text { mo. }\end{array}$ & $\begin{array}{c}\text { Mean } \\
\text { max } \\
\text { temp } \\
\text { prior 7- } \\
9 \text { mo. }\end{array}$ & $\begin{array}{c}\text { Mean } \\
\text { min } \\
\text { temp } \\
\text { prior 7- } \\
9 \text { mo. }\end{array}$ & Statistics \\
\hline emergence & + & & + & + & & & - & - & - & & & $\begin{array}{l}\mathrm{F}=17.4, \\
\mathrm{df}=6,20 \\
P<0.01 \\
\text { adj. } \mathrm{R}^{2}=0.79\end{array}$ \\
\hline growth & + & & & & + & & + & - & & - & - & $\begin{array}{l}\mathrm{F}=15.3, \\
\mathrm{df}=6,20, \\
P<0.01 \\
\text { adj. } \mathrm{R}^{2}=0.77\end{array}$ \\
\hline dehiscence & & + & & + & - & - & & - & - & - & - & $\begin{array}{l}\mathrm{F}=3.4, \\
\mathrm{df}=8,18, \\
P=0.01 \\
\text { adj. } \mathrm{R}^{2}=0.43\end{array}$ \\
\hline mortality & & & & & & & & & & & & $\begin{array}{l}\mathrm{F}=1.8, \\
\mathrm{df}=9,17, \\
P=0.13, \\
\text { adj. } \mathrm{R}^{2}=0.13\end{array}$ \\
\hline
\end{tabular}


Fig. 1. The epiphytic hand fern (Cheiroglossa palmata) on a cabbage palm (Sabal palmetto). Sporophores, which are fertile spikes that consist of a stalk and a sporangial cluster that bears two rows of sporangia, are shown in the rectangular box. Photo courtesy of Alan Cressler. Fig. 2. Mean monthly precipitation and mean maximum temperature ("max temp") and minimum temperature ("min temp") between June 2003 and May 2006 for the closest National Oceanic and Atmospheric Administration's weather station in Titusville, FL.

Fig. 3. Phenology from March 2004 through May 2006 in Central Florida, USA of A) emergence of new hand fern leaves, B) growth of leaves (percent change in length between two survey periods), and C) percentage of all leaves that had sporangia that dehisced since the prior survey. 


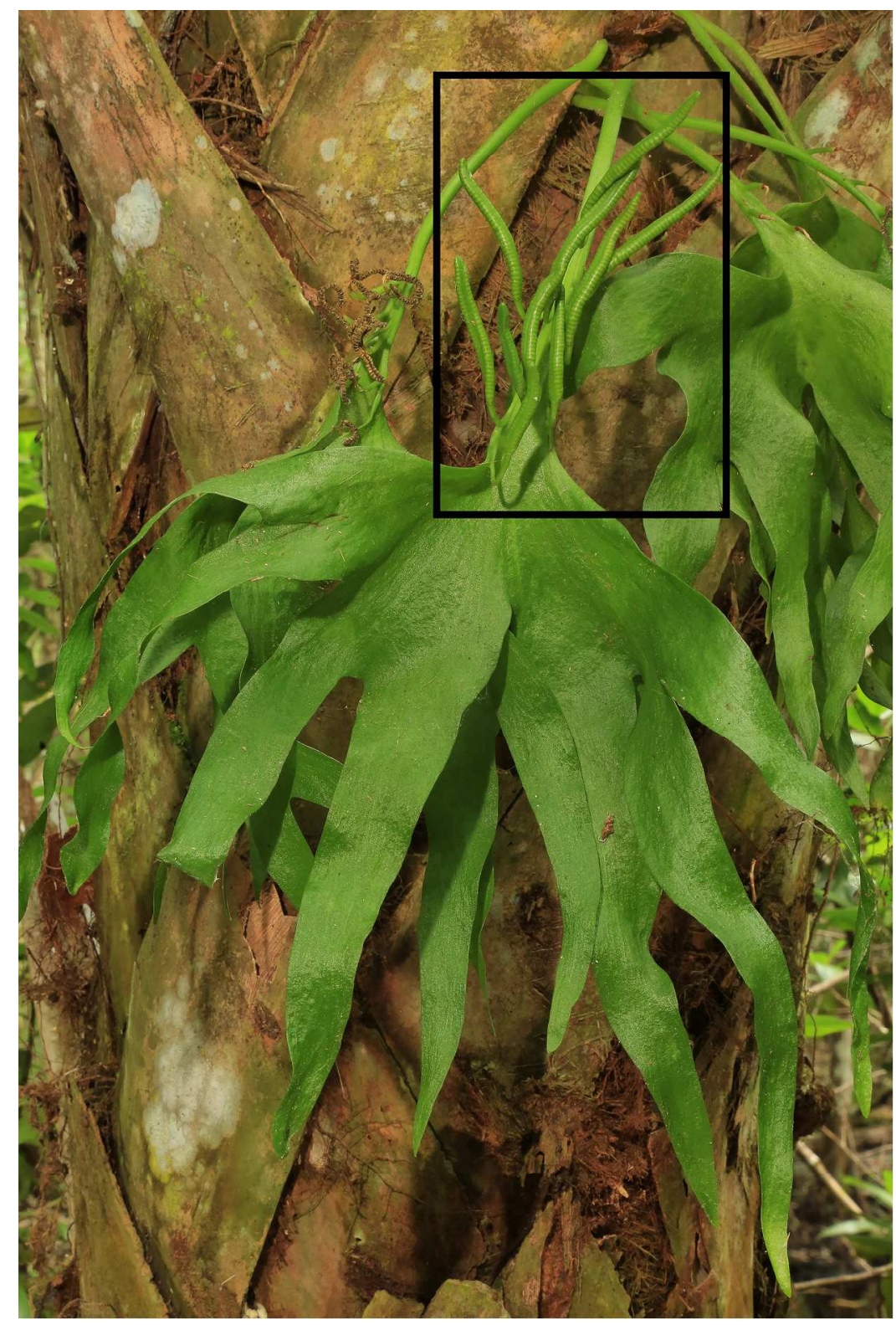

Fig. 1. The epiphytic hand fern (Cheiroglossa palmata) on a cabbage palm (Sabal palmetto). Sporophores, which are fertile spikes that consist of a stalk and a sporangial cluster that bears two rows of sporangia, are shown in the rectangular box. Photo courtesy of Alan Cressler.

$157 \times 236 \mathrm{~mm}(300 \times 300$ DPI $)$ 


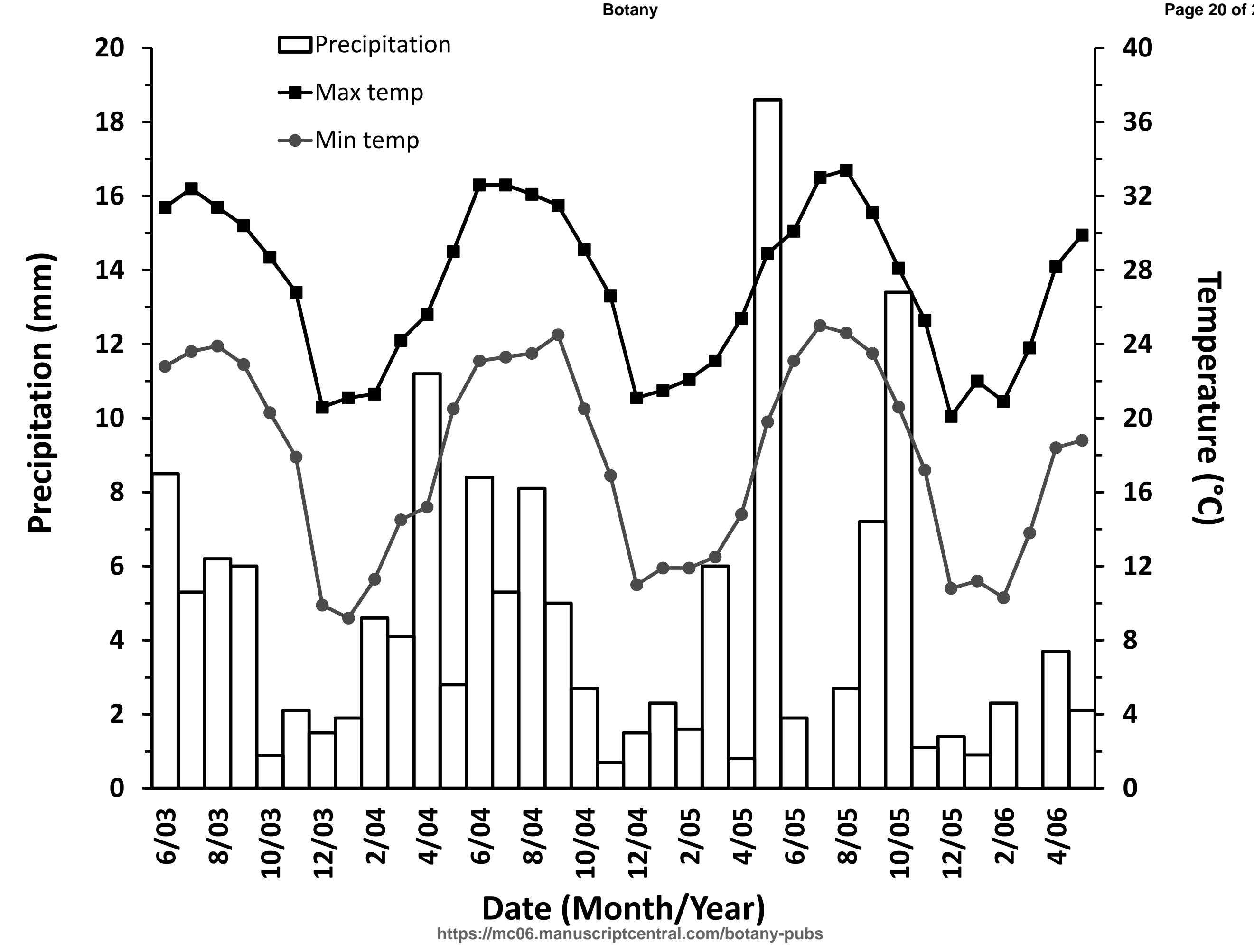




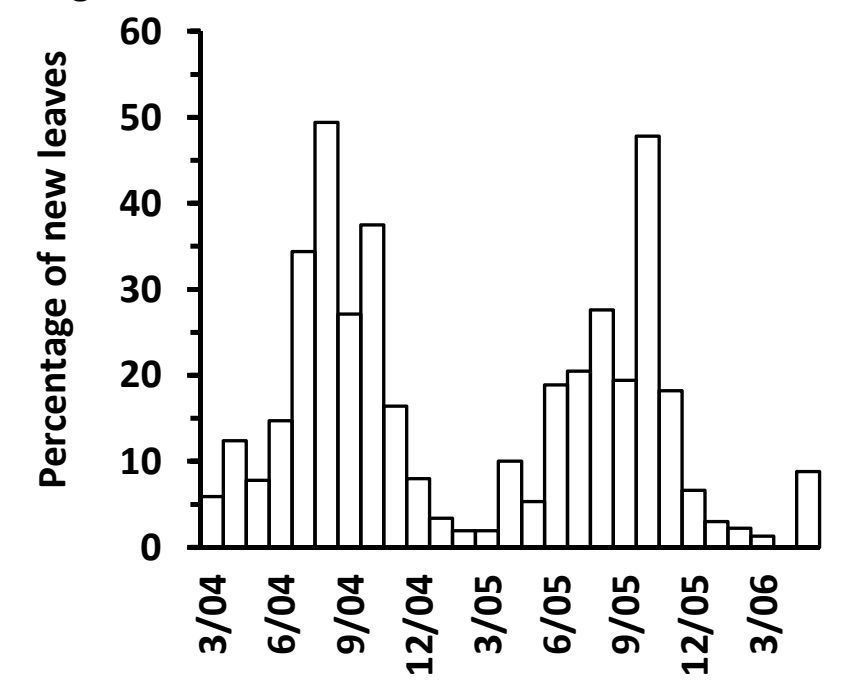

B

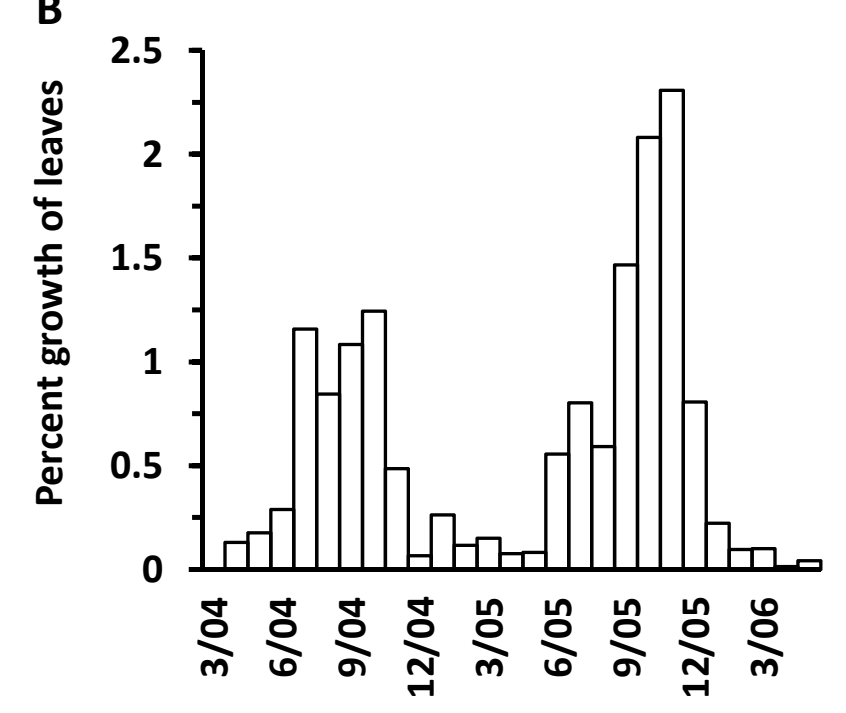

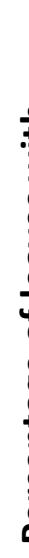

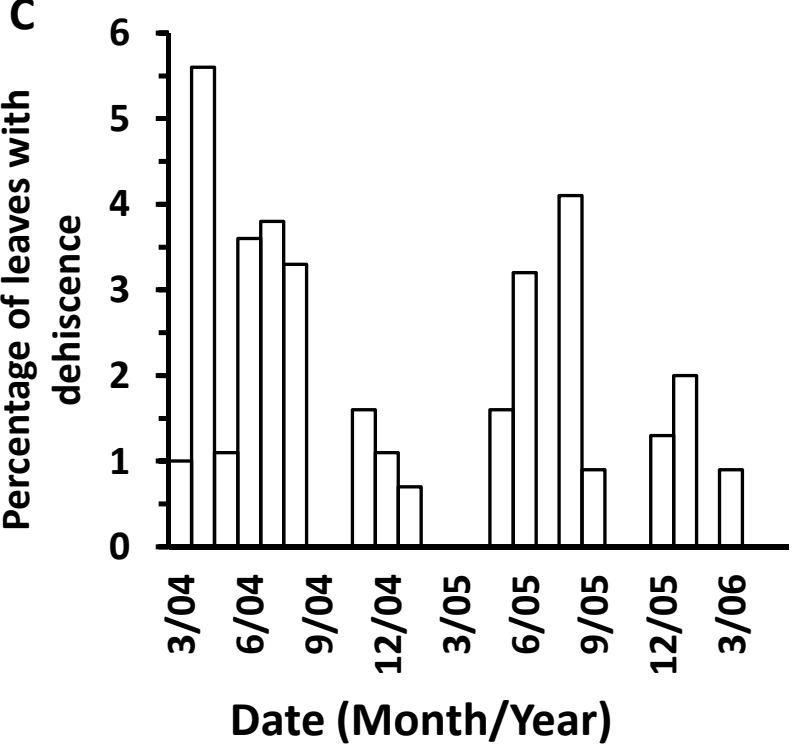

